\title{
LEGAL PROBLEMS OF INTERNATIONAL SECURITY IN THE \\ CURRENT ENVIRONMENT
}

\begin{abstract}
Rassokha Ekaterina Aleksandrovna
Student All-Russian State University of Justice (RLA of the Ministry of Justice of Russia)

Scientific advisor: Alexandrova Elena Valerievna
\end{abstract}

Abstract: The article reflects the main views on international security problems in the legal aspect and identified actual problems and contradictions in the application and compliance with international humanitarian law norms.

Key words: international security, international humanitarian law, actual problems, enforcement, global security.

Today, as well as years earlier, international organizations, together with the governments of states, are making repeated attempts to prevent global, regional and local international conflicts that arise for various reasons and take completely different forms. It cannot be said that these attempts are completely futile, but there is still no truly universal and reliable mechanism, primarily a legal one, that would be able not only to eliminate the consequences of outbreak of conflicts as quickly as possible, but also to nip them in the bud. The debate continues on how it is possible to develop this mechanism: whether it will be the creation of an international supra-governmental body, a world government, or the further development of already existing international organizations.

This article will provide an overview of the relationship between armed conflicts and other threats to global security to consider the adequacy and effectiveness of the existing international regulatory framework governing armed conflicts in the light of the broader problems facing the modern world community.

In recent years, categories of violence other than armed conflicts have become widespread, and social, save the economic, political and humanitarian 
consequences are rapidly increasing. Given the number of people affected by such violent situations, they should be viewed as a threat to global security similar to (or perhaps more serious) to armed conflicts.

When analyzing the legal framework of armed conflicts from a global security point of view, it should be noted that, in contrast to the rules governing the use of interstate force, the role of international humanitarian law in relation to global security is less obvious. Of course, it cannot be denied that international humanitarian law can contribute to global security, since greater adherence to its norms during armed conflicts would lead to significantly fewer casualties and less destruction and, as a result, would contribute to the reconciliation of the parties to conflicts. Moreover, better protection of civilian infrastructure would greatly contribute to economic and social recovery from armed conflict. However, it should be emphasized that the aim of international humanitarian law remains the regulation and mitigation of the consequences of armed conflicts, not their prevention. Thus, it is widely recognized that more efforts are needed to prevent armed conflict at the international level. However, confession alone is not enough.

With regard to international criminal law, a serious and truly universal fight against impunity for international crimes committed in armed conflict, with a high likelihood of prosecution, would probably have a preventive effect against serious violations of international humanitarian law.However, the world is still far from this utopia, and even the creation of the International Criminal Court has not altered the fact that in reality the impact of criminal law continues to depend mainly on the extent to which alleged war criminals are prosecuted at the national level. As long as the fight against impunity, both nationally and internationally, is subject to double standards and cannot be based on genuine political commitment, no significant contribution can be expected from International Criminal Law in enhancing respect for international humanitarian law.

According to the World Forum's 2020 Global Risks Report, four of the top five global risks in terms of likelihood are climate and environmental. 
Cyberattacks are also in the top ten. For example, cyberattacks, unlike cyberwar, are the undisputed leaders in any rating of Global Risks.

Indeed, according to Swiss Re Institute's 2020 SONAR: "New emerging risks insights," recurring and escalating cyberattacks are "already becoming a regular occurrence" while new forms of conflict are expected to emerge, including, quite possibly, and military conflict, even between major powers. Suffice it to consider the NIAC in Syria with the military participation of various world and regional powers on the opposing sides, the massive armament of the Gulf countries and the conflict in Yemen, as well as the growing tension between the "West" and Russia, which reveals an obvious potential for escalation.

For full disclosure of the topic of the article, it is necessary to draw a basic distinction between jus ad bellum and jus in bello. International law distinguishes between jus ad bellum - the right of a state to resort to the use of military force (including for the purpose of protecting territorial integrity and repelling aggression) - and jus in bello - the obligation of a party to an armed conflict to limit the means and methods of waging war to protect its victims, that is, respect international humanitarian law. The first principle is governed mainly by the UN Charter, according to which the UN Security Council has primary responsibility for the maintenance of international peace and security, while the UN General Assembly has additional responsibility under Articles 10, 11 and 14 of the Charter.

In accordance with Clause 4 of Article 2 of the UN Charter "all members must refrain in their international relations from the threat of the use of force against the territorial integrity or political independence of any state (...)".

However, in practice, this provision is not properly enforced. Threats to use force are regularly exchanged between states, and states are not accused of violating this article. Not long ago, in April 2018, reports of chemical weapons use by the Syrian army provoked punitive airstrikes by the United States, France and the United Kingdom in Syria, even before the Organization for the Prohibition of Chemical Weapons conducted its investigation. At the same time, the growing de facto international community's tolerance for the unilateral use of force against 
States has been accompanied by a clear increase in prima facie. Obviously, from the point of view of global security, these events cause great resonance. The number of people fleeing war, persecution and conflict exceeded 70 million worldwide in the same 2018 - the highest number recorded by UNHCR in almost seventy years of its activity.

The reality is that, under the guise of self-defense, unjustified military force is increasingly being used to assert political influence and prevent adverse shifts in the regional balance of power. It is not surprising, therefore, that such actions are rarely limited to what is necessary or proportionate to address the perceived threat, and often trigger a prolonged downward spiral marked by the collapse of civilian governance structures and the spread of violence.Today, violations of paragraph 4 of Article 2 of the UN Charter rarely entail negative consequences that go beyond verbal condemnation of varying degrees, especially in cases where an aggressor state can count on the support of one of the five permanent members of the UN Security Council.

This issue is becoming increasingly topical due to the fact that in addition to situations of armed attacks requiring the immediate use of force for the purpose of self-defense, the UN Security Council must retain primary responsibility for the maintenance of international peace and security and the sole authority to authorize the individual or collective use of military force with this goal.

In the event that the existing norms of international humanitarian law are not interpreted with the due measure of respect, self-defense for the aggressor states will soon become a means of justifying political ambitions.

From a national security perspective, violations of international humanitarian and human rights law are sometimes perceived as less of a threat to global security than violations of jus ad bellum. In reality, however, particularly widespread or systematic violations of international humanitarian law can have significant destabilizing and escalating potential.

The heightened reluctance of states to conclude legally binding treaties in the field of international humanitarian law is striking, especially given that 
international responsibility in the event of a breach of international obligations the state has only little tangible consequences.

Unfortunately, widespread disregard for international humanitarian law - in particular the principles of warfare such as proportionality and precaution - is a daily occurrence. The widespread disregard for the principle of proportionality is reminiscent of the days of "just war" when revenge was considered acceptable. In this regard, humanitarian organizations, as a rule, widely welcome any new agreement that can be equated with a humanitarian agreement, more recently these agreements have been mainly related to weapons. At the same time, it is indicative that the most powerful states do not ratify these agreements and, therefore, do not consider themselves bound by them.

In particular, issues related to nuclear weapons are considered mainly within the framework of the Treaty on the Non-Proliferation of Nuclear Weapons (NPT). The last NPT conference in 2019 showed that proposals that are not endorsed by nuclear powers tend not to be put forward. While non-proliferation and nuclear disarmament are overarching goals of the NPT regime, they are not necessarily pursued equally by all countries.

In addition, some States that are important exporters or importers of weapons appear to benefit from protracted armed conflicts and security threats.

Therefore, there is no doubt that the devastating impact of armed conflict on the socio-economic situation would be much less if the basic principles of humanitarian law, such as the rule of distinguishing between combatants and civilians, as well as military and civilian objects, were better respected. affects the socio-economic situation of the state on whose territory the conflict erupts.

As the National Intelligence Council of the United States quite rightly noted in its report in January 2017, according to which the maximum threat of armed conflicts is predicted in the world in the next five years since the Cold War, this has been possible due to the diverging interests of the major powers. The report also argues that all these factors, if they do not lead to a world war, can cause the division of the world into spheres of influence. Other factors stand out: regional 
conflicts, terrorism, growing economic inequality, problems of nationalism and anti-globalism, as well as a slowdown in economic growth and environmental problems. At the same time, the report does not exclude that governments will be able to orient themselves in the new conditions and build a more stable society.

As the above analysis shows, the above-mentioned international legal framework has hardly proved its effectiveness in preventing armed conflicts or provoked their consequences.Reflecting on the countless images and reports of destroyed cities and civilian casualties, it seems clear that applicable international law and the work of the UN Security Council have failed to achieve their goal of "saving succeeding generations from the scourge of war." Despite this, the negative consequences of armed conflicts would certainly be much worse in the absence, in particular, of the relevant norms of international humanitarian law.

Armed conflicts continue to pose one of the main threats to global security at all levels, and therefore, their prevention must be absolutely central to any sustainable system of global development. Today, the world is in dire need of new, more effective and rational means of preventing and eradicating conflicts at all levels, as well as eliminating their consequences. 
1. Osipyan B.A. Prospects for the global development of law // Modern Law. 2004. No. 2. S. 44-48.

2. Osipyan B.A. The initial inconsistency of the idea of a world state // Problems of jurisprudence. 2013. No. 4. S. 427-439.

3. A.Ya. Kapustin International humanitarian law. M., 2009. S. 11.

4. Melzer, N. International humanitarian law. General course: educational and reference edition. Access mode: http://www.redcross.ru/ sites / default / files / books / mezhdunarodnoe_gumanitarnoe_pravo_obshchiy_kurs.pdf

5. Mishkuro, M.A. Correlation of the concepts of "war" and "armed conflict" in international humanitarian law // Young scientist. - 2016. - No. 8. - S. 763 765. - Access mode: https://moluch.ru/archive/ 112/28160 /

6. Smolnikov O.Yu., Shapochka A.G. The Red Cross and International Humanitarian Law in the Modern World. M., 1989. S. 9.

7. Geneva Conventions of August 12, 1949 and Additional Protocols thereto. - M .: Knowledge, 1994. -246 p.

8. Charter of the United Nations 1 UNTS XVI (UN Charter) art 24 (1). See, also, Certain Expenses of the United Nations (Article 17, paragraph 2, of the Charter) (Advisory Opinion) [1962] ICJ Rep 151, 163.

9. Certain Expenses (n 38); also Higgins et al, Oppenheim's International Law: United Nations (vol 2, OUP 2017) 963-73; Leserbrief von Dr Hansjörg Döpp (FAZ, 2 February 2018).

10. UNHCR, 'Global Trends Report: Forced Displacement in 2018' (2019) 2 (https://www.unhcr.org/5d08d7ee7.pdf) accessed 26 April 2020.

11. Zygmunt Bauman, Community: Seeking Safety in an Insecure World (Polity 2001) 145. 